\title{
Chapter 1 \\ Rice Straw Overview: Availability, Properties, and Management Practices
}

\author{
Nguyen Van Hung, Monet Concepcion Maguyon-Detras, \\ Maria Victoria Migo, Reianne Quilloy, Carlito Balingbing, Pauline Chivenge, \\ and Martin Gummert
}

\begin{abstract}
Managing rice straw remains a challenge in Asia where more rice, and hence, more straw, is grown each year to meet rising demand. The widespread burning of rice straw is a major contributor to dangerously high levels of air pollution in South- and Southeast Asia associated with health issues. At the same time, researchers, engineers, and entrepreneurs are developing a range of alternative uses that turn rice straw into a commodity around which sustainable value chains can be built to benefit rural people. The best alternative to burning rice straw in any one location depends on context. However, available information remains scattered in different media and no publication yet exists that helps people learn about, and decide between, rice straw management options. This book provides a synthesis of these options and integrates knowledge on relevant areas: sustainable rice straw management practices, rice straw value chains, and business models. The book is also based on new research and practice data from research organizations and innovators in Vietnam, the Philippines, and Cambodia.
\end{abstract}

Keywords Rice $\cdot$ Rice straw $\cdot$ Residue $\cdot$ Sustainable $\cdot$ Rice straw management

\footnotetext{
N. V. Hung $(\bowtie) \cdot$ R. Quilloy $\cdot$ C. Balingbing $\cdot$ P. Chivenge $\cdot$ M. Gummert International Rice Research Institute (IRRI), Los Baños, Laguna, Philippines e-mail: hung.nguyen@irri.org; r.quilloy@irri.org; c.balingbing@irri.org; p.chivenge@irri.org; m.gummert@irri.org

M. C. Maguyon-Detras · M. V. Migo

Department of Chemical Engineering, College of Engineering and Agro-Industrial Technology, University of the Philippines Los Baños (UPLB),

Los Baños, Laguna, Philippines

e-mail: mmdetras@up.edu.ph; mpmigo@up.edu.ph
} 


\subsection{Rice Straw Availability}

Rice straw is a residual byproduct of rice production at harvest. The total biomass of this residue depends on various factors such as varieties, soils and nutrient management and weather. At harvest, rice straw is piled or spread in the field depending on the harvesting methods, using stationary threshers or self-propelled combine harvesters, respectively. The amount of rice straw taken off the field depends mainly on the cutting height (i.e., height of the stubble left in the field). Rice straw that remains in the field after harvest can be collected, burned, or left to decompose (soil incorporation). The "stubble" — the uncut portion of the rice straw after harvestremains, and can be burned or incorporated into the soil in preparation for the next crop. The ratio of straw to paddy varies, ranging from 1.0 to 4.3 (Zafar 2015) and 0.74-0.79 (Nguyen-Hung et al. 2016a). We investigated biomass ratios for a common rice variety (NSIC Rc158) at IRRI in 2017 that resulted in the findings shown in Fig. 1.1 (unpublished). Yield of the total straw biomass ranges from 7.5 to $8 \mathrm{t} / \mathrm{ha}$ while removed straw (harvested with leftover grains) ranged from 2.7 to 8 t/ha corresponding to the cut portion ranging from $50 \%$ to $100 \%$ of the total straw biomass. Figure 1.2 shows the global minimum and maximum estimate of rice straw avail-

Fig. 1.1 Biomass ratios of rice production for the NSIC Rc158 variety grown at IRRI during the 2017 dry season

Fig. 1.2 Annual Rice production and rice straw availability in SEA, the rest of Asia, and the rest of the World

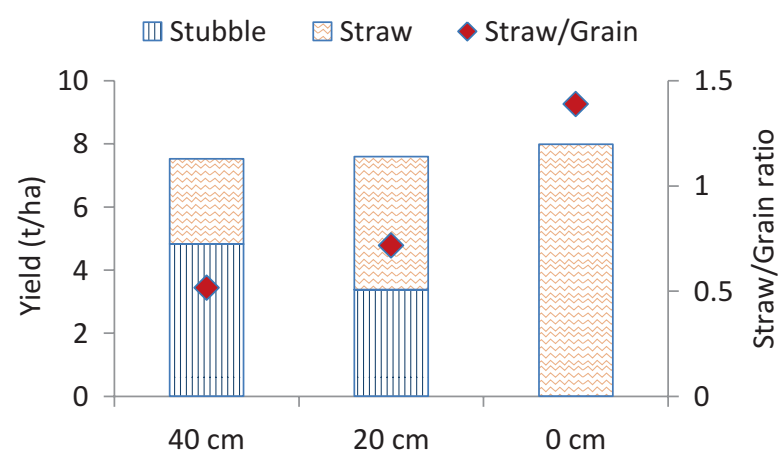

Cutting height of remained stubble

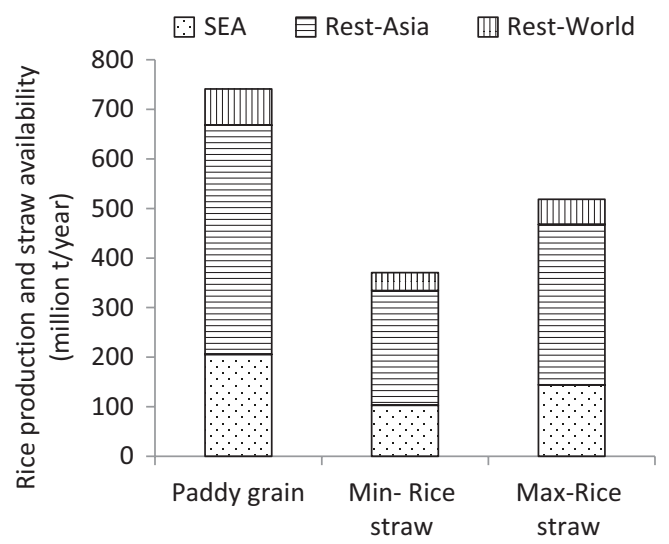


ability based on global rice production data (IRRI 2019) and the straw:grain ratios of 0.5 and 0.7 from the experiment.

Annual rice straw production is in the ranges of 100-140, 330-470, and 370-520 million t/year in Southeast Asia (SEA), the whole of Asia, and over the world, respectively (Fig. 1.2).

\subsection{Rice Straw Properties and Composition}

Utilization of rice straw is dependent on its characteristics, which can be divided into three major categories: (1) physical properties, (2) thermal properties, and (3) chemical composition. Physical properties include bulk density, heat capacity, and thermal conductivity. Density is the most relevant to the handling and storage of rice straw. Thermal properties, and heating value; these properties are relevant when biomass is converted to energy. Chemical composition, such as lignin, cellulose, hemicellulose/carbohydrates, and nutrient contents, are relevant to applications, such as for livestock feed and soil fertility. Characterizing rice straw is helpful for life cycle analysis and efficiency calculations. The most common methods used in the characterization of rice straw can be referenced from the National Renewable Energy Laboratory (NREL) and the American Society for Testing and Materials (ASTM).

\subsubsection{Physical Properties}

Based on various studies, the bulk density of rice straw can vary depending on the different forms it may take. Loose rice straw, collected directly from the field, can range in density from 13 to $18 \mathrm{~kg} \mathrm{~m}^{-3}$ in dry matter (dm) (Migo 2019). Chopped straw, ranging in length from 2 to $10 \mathrm{~mm}$ (Chou et al. 2009), can have a density range of from 50 to $120 \mathrm{~kg} \mathrm{~m}^{-3}$ (Liu et al. 2011), depending on the equipment used. Depending on the baler equipment used, baled straw size and the compression ratio, and thus bulk density, will vary. A round rice straw bale with a 70-cm length and 50 -cm diameter has a bulk density ranging from 60 to $90 \mathrm{~kg} \mathrm{~m}^{-3} \mathrm{dm}$ (Nguyen-VanHung et al. 2016b). The density of rice straw briquettes with a $90-\mathrm{mm}$ diameter and 7- to $15-\mathrm{mm}$ thickness is $350-450 \mathrm{~kg} \mathrm{~m}^{-3} \mathrm{dm}$ (Munder 2013). The density of rice straw pellets with an $8-\mathrm{mm}$ diameter and from 30 to $50 \mathrm{~mm}$ in height is 600 $700 \mathrm{~kg} \mathrm{~m}^{-\mathbf{3}} \mathrm{dm}$ (Nguyen-Van-Hieu et al. 2018).

As compared to rice husks, which have a density of between 86 and $114 \mathrm{~kg} \mathrm{~m}^{-3}$ (Mansarav and Ghaly 1997), unprocessed, loose rice straw has a low density. This means a higher volume per kilogram, implying higher shipping and handling costs as well as more complications in processing, transportation, storage, and burning (Duan et al. 2015, Liu et al. 2011). Rice straw volume can be reduced through processing but this will require additional energy inputs. Various size-reduction methods can increase density of the straw including using of pellet mills (Nguyen-V-Hieu 
et al. 2018), roller presses, piston presses, cubers, briquette presses, screw extruders, tabletizers, and agglomerators (Satlewal et al. 2017).

When used for bioenergy, rice straw's bulk density influences the combustion process as it affects the time required in the reactor (Zhang et al. 2012). Rozainee et al. (2008), as cited by Zhang et al. (2012), reported that a low bulk density causes poor mixing and nonuniform temperature distribution (unfavorable operating conditions), which decreases energy efficiency.

The moisture content of rice straw is an important consideration when determining how to process it and what it will be used for. For example, moisture content affects the heating value of the straw, which is important when the byproduct is intended for use as bioenergy. In addition, if rice straw volume is to be reduced, the moisture content before compression should be between 12 and 17\% (Kargbo et al. 2010). Unfortunately, the moisture content can fluctuate greatly due to the method and duration of the straw's storage (Topno 2015).

\subsubsection{Thermal Properties}

The calorific value is an essential parameter that shows the energy value of rice straw, if to be used for bioenergy. Rice straw's energy efficiency can be calculated by dividing its energy output by its calorific value, which may be expressed as the higher-heating value (HHV), wherein latent heat of the water is included, or lowerheating value (LHV). In terms of calorific value, rice straw has an HHV that ranges from 14.08 to $15.09 \mathrm{MJ} \mathrm{kg}^{-1}$, as determined by different studies as shown in Table 1.1 and is comparable to rice husks with a calorific value of around 14.2 $\mathrm{MJ} \mathrm{kg}^{-1}$. However, the calorific value of rice straw is just one-third of that of kerosene, which has a calorific value of $46.2 \mathrm{MJ} \mathrm{kg}^{-1}$.

In the proximate analysis, volatiles refer to the volatile carbon, combined water, net hydrogen, nitrogen, and sulfur, which are first driven off in combustion. Rice straw is characterized by high volatiles or volatile matter (VOM) (60.55-69.70\%), which is comparable to the biomass of other byproducts, such as sugar cane bagasse, corn straw, wheat straw, etc. In bioenergy applications, specifically in combustion, a high VOM has advantages, such as easier ignition and burning; but it also leads to a rapid, more difficult-to-control combustion (Liu et al. 2011). Fixed carbon refers to the carbon left after the volatiles are driven off. Rice straw has a fixed carbon ranging from $11.10 \%$ to $16.75 \%$, which is also comparable to other biomass.

The ultimate analysis reveals the elemental carbon, hydrogen, oxygen, nitrogen, and sulfur composition of rice straw. Compared to fossil fuels, the carbon content of rice straw biomass is less, while the oxygen and hydrogen contents are higher. As shown in Fig. 1.3, the van Krevelen diagram shows the hydrogen-to-carbon (H:C) and oxygen-to-carbon (O:C) ratios of various fuels. The ranges of $\mathrm{H}: \mathrm{C}$ and $\mathrm{O}: \mathrm{C}$ in rice straw are 1.1-1.36 and 0.94-1.06, respectively, which place it in the biomass region of the van Krevelen diagram, specifically in the cellulose region.

Rice straw ash content, which includes noncombustible residues, is around 18.67-29.1\%. The high silica content of rice straw (Table 1.2) causes erosion prob- 


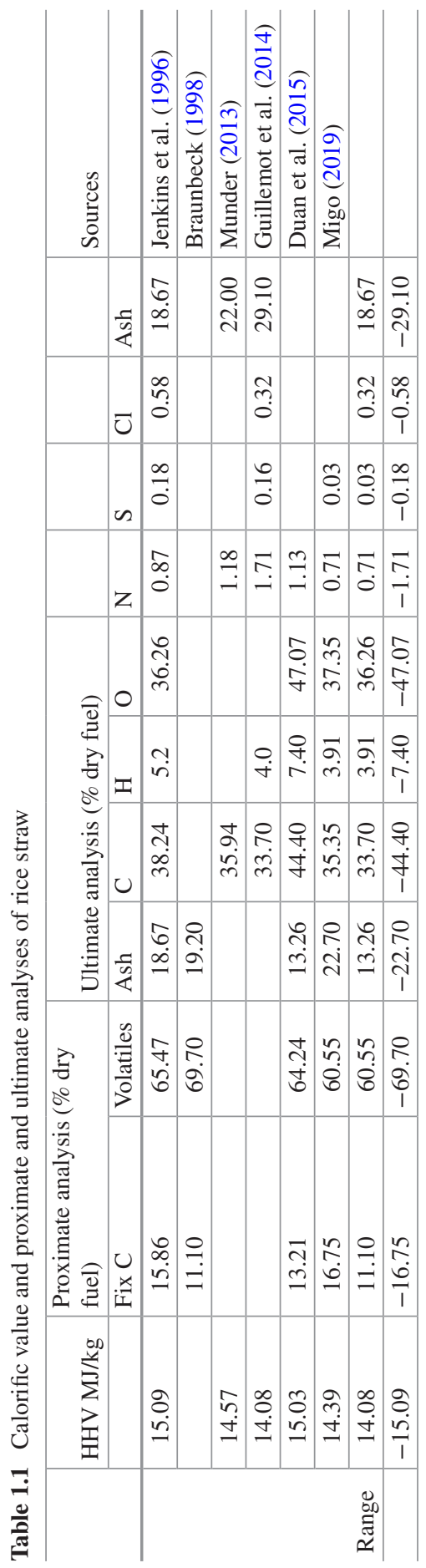




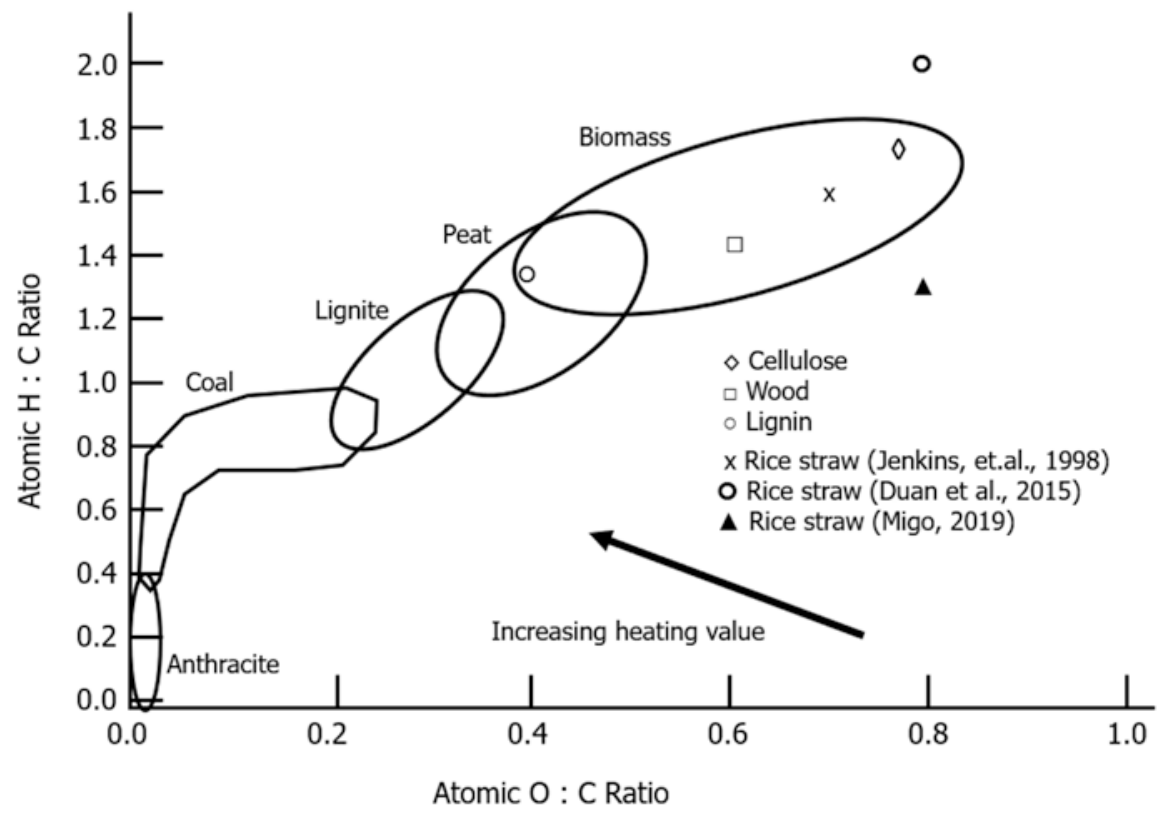

Fig. 1.3 Van Krevelen diagram for various solid fuels. Source: Adapted from Mando (2013)

Table 1.2 Rice straw ash properties

\begin{tabular}{l|c|c|c|c|c|c|c|c|c|l|l}
\hline & $\mathrm{SiO}_{2}$ & $\mathrm{Al}_{2} \mathrm{O}_{3}$ & $\mathrm{TiO}_{2}$ & $\mathrm{Fe}_{2} \mathrm{O}_{3}$ & $\mathrm{CaO}$ & $\mathrm{MgO}$ & $\mathrm{Na}_{2} \mathrm{O}$ & $\mathrm{K}_{2} \mathrm{O}_{3}$ & $\mathrm{SO}_{3}$ & $\mathrm{P}_{2} \mathrm{O}_{5}$ & Sources \\
\hline $\begin{array}{l}\text { \% of ash } \\
\text { (d.b) }\end{array}$ & 75.00 & 1.40 & 0.02 & 2.00 & 1.50 & 1.90 & 1.90 & 10.00 & 0.90 & 2.70 & $\begin{array}{l}\text { Liu, et al. } \\
(2011)\end{array}$ \\
\hline & 74.67 & 1.04 & 0.09 & 0.85 & 3.01 & 1.75 & 0.96 & 12.30 & 1.24 & 1.41 & $\begin{array}{l}\text { Jeng, et al. } \\
(2012)\end{array}$ \\
\cline { 2 - 13 } & 82.60 & 1.10 & 0.60 & 1.00 & 3.30 & 1.70 & 0.30 & 6.30 & 0.90 & 1.70 & $\begin{array}{l}\text { Guillemot } \\
(2014)\end{array}$ \\
\hline & 67.78 & 1.54 & & & 2.08 & 1.11 & 1.48 & 11.87 & & & Migo (2019) \\
\hline Range & 67.78 & 1.04 & 0.02 & 0.85 & 2.08 & 1.11 & 0.30 & 6.30 & 0.90 & 1.41 & \\
\hline
\end{tabular}

lems in processing machines (for example, in conveyers and grinders), boilers, and decreases the digestibility of rice straw when used as fodder. Rice straw is also characterized by a high volatile matter as compared to wood and coal; and a lower fixed carbon compared than that in coal. The high ash content in rice straw decreases its calorific value and causes problems in energy conversion. A high potassium and alkali content in ash may increase corrosion and fouling problems in grates, since alkali metals are known triggers for these phenomena. Table 1.3 shows the ash analysis of rice straw. 


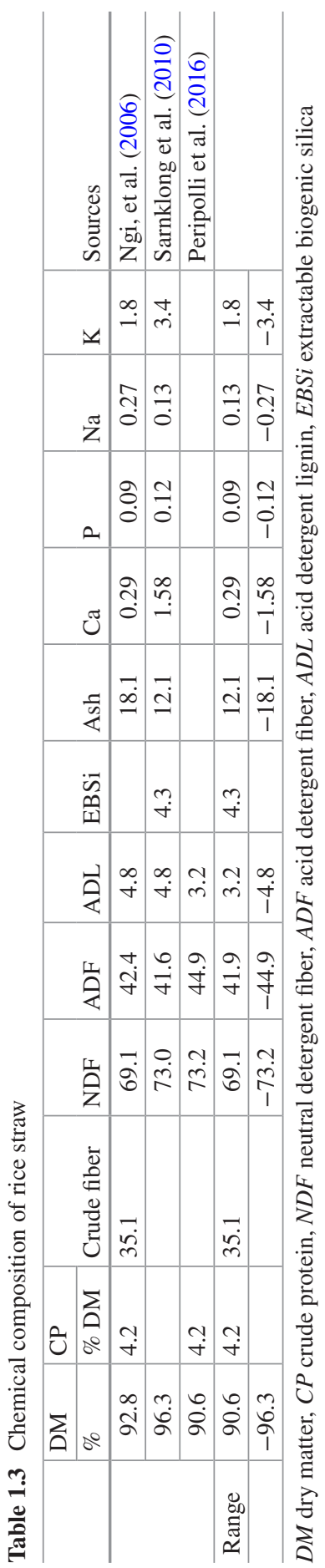




\subsubsection{Chemical Composition}

Chemical composition determines the nutritional quality of rice straw, which is important for livestock feed, anaerobic digestion, and as a soil amendment. Rice straw has low nutritional value and research has been done to improve it. Jenkins (1998) indicated that the typical components of plant biomass are moisture cellulose, hemicelluloses, lignin, lipids, proteins, simple sugars, starches, water, hydrocarbon, ash, and other compounds. The concentrations of these compounds depend on the plant species, type of tissue, growth stage, and growing conditions. Rice straw is considered a lignocellulosic biomass that contains $38 \%$ cellulose, $25 \%$ hemicellulose, and 12\% lignin (Japan Institute of Energy 2002). Compared to the biomass of other plants, such as softwood, rice straw is lower in cellulose and lignin and higher in hemicellulose content (Barmina et al. 2013). Table 1.3 shows the compositional analysis of rice straw via the work of various researchers.

\subsection{Overview of Rice-Straw Management Options}

\subsubsection{Burning Issues and Alternative Management Options}

Intensification of rice-cropping systems has been associated with the use of highyielding and short-duration varieties with shorter turnaround time between crops in multi-cropping systems. Furthermore, the rapid introduction of combine harvesters constitutes a game changer because of the larger amounts of straw that are left spread out on the field. Manual collection of the straw in the field is unprofitable because of the high labor cost. Incorporation in the soil poses challenges in intensive systems with two to three cropping rounds per year. This is due to the insufficient time for decomposition, leaving the straw with poor fertilization properties for the soil and hindering crop establishment. As a result, open-field burning of straw has increased dramatically over the last decade, despite being banned in most ricegrowing countries because of pollution and the associated health issues. Therefore, it is important to look for sustainable solutions and technologies that can reduce the environmental footprint and add value by increasing the revenues of rice production systems. Options for rice-straw management are shown in Fig. 1.4. Rice straw can inherently be used for soil conditioning thru composting and carbonization; as well as for bio-energy production and for materials recovery such as silica and bio-fiber (for industrial use). It is important to note that not all the possible options are economically viable. This is due to the fact that the processing material and transportation costs in value-adding solutions are still higher as compared to using the other more traditional options. 


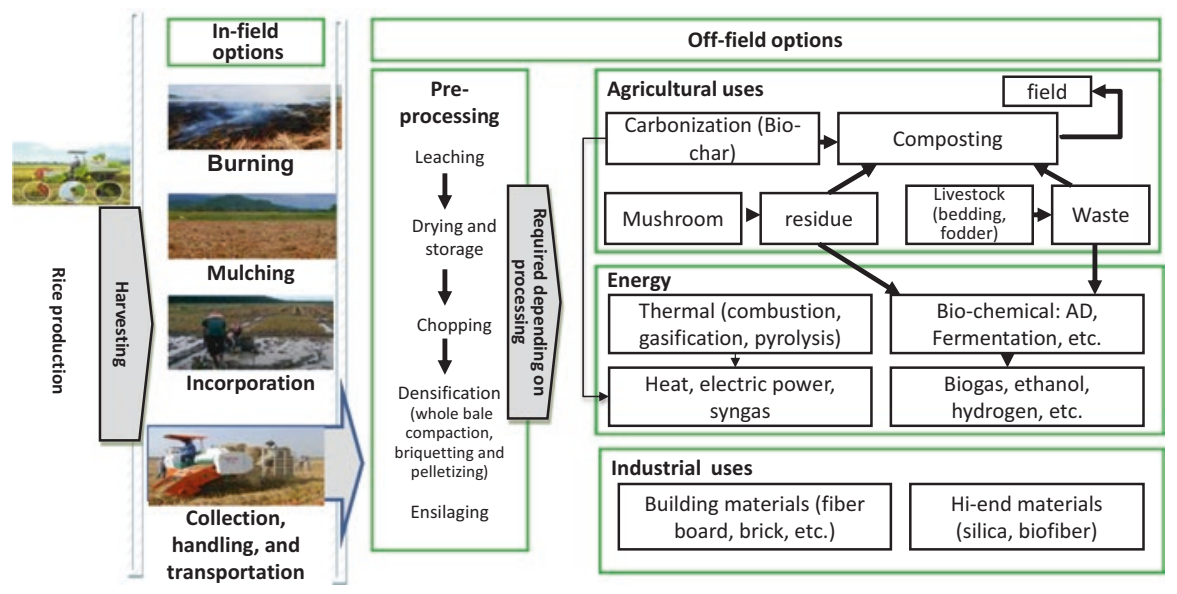

Fig. 1.4 Rice-straw management options

\subsubsection{Scalable Solutions for Sustainable Rice-Straw Management}

\subsubsection{Incorporation}

Rice straw incorporation into soil is another common management option, but adequate time must be allowed for its decomposition to ensure effectiveness and production efficiency (Mandal et al. 2004; Yadvinder-Singh et al. 2004; Dobermann and Fairhurst 2002). Additionally, careful straw management considerations have to be made after soil incorporation for greenhouse gas emission (GHGE) (Sander et al. 2014). Rice straw is characterized by a slow decomposition rate; thus, some farmers avoid rice straw soil incorporation especially in intensive cropping systems with 3 weeks interlude. In terms of total carbon dioxide equivalent $\left(\mathrm{CO}_{2}\right.$-eq) per ha converted from $\mathrm{CH}_{4}$ and $\mathrm{N}_{2} \mathrm{O}$, recent researches at IRRI showed that rice straw soil incorporation emitted about from 3500 to $4500 \mathrm{~kg} \mathrm{CO}_{2}$-eq ha ${ }^{-1}$ (Rosamanta 2017) which is about 1.5-2.0 times higher than when rice straw was removed. In response to this, researchers have conducted studies to evaluate using fungal inocula to speed up the decomposition rate (Goyal and Sindhu 2011, Ngo-T-T-Truc et al. 2012). Rice straw is chopped with combine harvesters and then sprayed with an inoculum to foster its decomposition in the soil. This management option is discussed in more detail in Chap. 9. 


\subsubsection{Mechanized Collection}

Combine harvesters are known to spread rice straw across the field. Therefore, since rice straw collection is energy intensive, it is only economically viable and practical thru mechanical collection by use of balers. Collection plays a critical role in the rice straw supply chain. A discussion on different rice straw balers used in Asia is presented in Nguyen-V-Hung et al. (2017). Mechanized collection technologies are discussed in more detail in Chap. 2.

\subsubsection{Mechanized Composting}

Rice straw composting is done by adding animal manure and enzymes to rice straw and mixing by a turner and ensilage, in order to homogenize the mixture. The biophysical processes of decaying matter can drastically improve thru mechanized composting. In turn, the compost can serve as fertilizer for growing vegetables and other crops, or can be used directly as soil conditioner. As soil conditioner, it improves the nutrient and organic matter content of the soil. This technology is described in more detail in Chap. 3.

\subsubsection{Mushroom Production}

The species of rice-straw mushrooms, Volvariella volvacea, is commonly used because of it grows easily and has a short growth duration of 14 days. The species grows in tropical weather at around $30-35^{\circ} \mathrm{C}$ for the mycelia development stage, and at around $28-30{ }^{\circ} \mathrm{C}$ for the fruiting body production stage. The main inputs for mushroom growing are rice straw, spawn, labor, and water. The mushroom harvest usually starts during the third week after inoculation and ends 1 week later. Outdoor mushroom production is a common practice in Vietnam's Mekong River Delta (MRD). The low investment cost is an advantage of this income-generating enterprise. It produces a yield of $0.8 \mathrm{~kg}$ of mushrooms per $10 \mathrm{~kg}$ of dried straw and generates a net profit of USD 50-100 $\mathrm{t}^{-1}$ of straw. Indoor production is a less common practice because of higher investment costs and the necessary strict control of the growing conditions. On the other hand, indoor mushroom growing produces about a 2-kg higher yield per $10 \mathrm{~kg}$ of dried straw. See Chap. 7 for more details on mushroom production.

\subsubsection{Rice-Straw Silage for Cattle Feed}

Rice straw is of poor quality to serve as a livestock feed. It has a low $\mathrm{C}: \mathrm{N}$ ratio and high NDF and ADF, which affects its nutritive value. Nevertheless, it is considered as a potential feed additive for increasing the energy and protein content. The prescribed consumption limit of rice straw by ruminants is 1.0 to $1.5 \mathrm{~kg}$ per $100 \mathrm{~kg}$ 
live-weight per day (Drake et al. 2002). Urea treatment of straw, which is rice straw ensilaged with $2-4 \%$ urea can improve consumption and digestibility of the rice straw as fodder. This technology is discussed in more detail in Chap. 7.

\subsection{Conclusions and Recommendations}

Upgrading the value chain of rice straw-byproducts and employing sustainable straw-management practices are the key to influencing farmers not to do open-field burning and thus avoid the negative environmental and health consequences. Incorporating rice straw into the soil is an option; however, it needs to be considered carefully to ensure timely decomposition and to minimize GHGE. Mechanized collection with balers plays a critical role in the sustainable use of rice straw. Alternative straw management options, such as straw-based mushroom and feed production, mechanized composting to produce organic fertilizer, etc., are discussed in the remaining chapters of the book.

This book focuses on the scalable options that will add economic value to rice production in Asia. Reviewed and updated information as well as scientific evidence on sustainable rice-straw management will be useful for further developments and related policies. Topics for another publication could be how rice straw can be used to produce biofuel and high-end materials, such as bioplastics, biofibers, and silica.

\section{References}

Barmina I, Lickrastina A, Valdmanis R, Zake M, Arshanitsa A, Solodovnik V, Telysheva G (2013) Effects of biomass composition variations on gasification and combustion characteristics. Engineering for rural development. Jelgava 05:23-24

Braunbeck CM (1998) Development of a rice husk furnace for preheating of the drying air of a low temperature drying system, $\mathrm{PhD}$ thesis, University of Hohenheim

Chou C, Lin S, Lu W (2009) Preparation and characterization of solid biomass fuel made from rice straw and rice bran. Fuel Process Technol 90(7-8):980-987

Dobermann A, Fairhurst TH (2002) Rice straw management. Better Crops International, vol 16, Special supplement, May 2002. http://www.ipni.net/publication/bci.nsf/0/163087B956D0EFF 485257BBA006531E8/\$FILE/Better\%20Crops\%20International\%202002-3\%20p07.pdf

Drake D, Nader G, Forero L (2002) Feeding rice straw to cattle. Publication 8079. University of California. Division of Agriculture and Natural Resources. http://anrcatalog.ucdavis.edu

Duan F, Chyang C, Zhang L, Yin S (2015) Bed agglomeration characteristics of rice straw combustion in a vortexing fluidized-bed combustor. Bioresour Technol 183:195-202

Goyal S, Sindhu SS (2011) Composting of rice straw using different inocula and analysis of compost quality. Microbiol J 4:126-138

Guillemot A, Bruant R, Pasquiou V, Boucher E (2014) Feasibility study for the implementation of two ORC power plants of 1 MWe each using rice straw as a fuel in the context of a publicprivate partnership with the institutions PhilRice and UPLB. ENERTIME, Courbevoie

IRRI (International Rice Research Institute) (2019) World rice statistics. http://ricestat.irri. org:8080/wrsv3/entrypoint.htm 
Japan Institute of Energy (2002) Asian biomass handbook: a guide for biomass production and utilization. http://www.build-a-biogas-plant.com/PDF/AsianBiomassHandbook2008.pdf

Jeng SL, Zainuddin AM, Sharifah RWA, Haslenda H (2012) A review on utilisation of biomass from rice industry as a source of renewable energy. Renew Sust Energ Rev 16:3084-3094

Jenkins BM (1998) Physical properties of biomass. In: Kitani O, Hall CW (eds) Biomass handbook. Gordon and Breach, New York

Jenkins BM, Bakker RR, Wei JB (1996) On the properties of washed straw. Biomass Bioenergy 10(4):177-200

Kargbo F, Xing J, Zhang Y (2010) Property analysis and pretreatment of rice straw for energy use in grain drying: a review. Agric Biol J N Am 1(3):195-200

Liu Z, Xu A, Long B (2011) Energy from combustion of rice straw: status and challenges to China. Energy Power Eng 3:325-331

Mandal KG, Misra AK, Hati KM, Bandyopadhyay KK, Ghosh PK, Mohanty M (2004) Rice residue management options and effects on soil properties and crop productivity. Food Agric Environ 2:224-231

Mando M (2013) Direct combustion of biomass. Book chapter. In: Biomass combustion science, technology and engineering. Erscheinungsort nicht ermittelbar: Woodhead Publishing

Mansarav KG, Ghaly AE (1997) Physical and thermochemical properties of rice husk. Energy Sources J 19(9). https://doi.org/10.1080/00908319708908904

Migo MVP (2019) Optimization and life cycle assessment of the direct combustion of rice straw using a small scale, stationary grate furnace for heat generation. Unpublished Masters thesis. University of the Philippines Los Baños

Munder S (2013) Improving thermal conversion properties of rice straw by briquetting. Masters thesis. University of Hohenheim

Ngi J, Ayoade JA, Oluremi OIA (2006) Evaluation of dried cassava leaf meal and maize offal as supplement for goats fed rice straw in dry season. Livest Res Rural Dev 18(9). https://www. feedipedia.org/node/3008

Ngo-T-T-Truc, Zenaida MS, Maria VOE, Enrique PP, Corazon LR, Florencia GP (2012) Farmers' awareness and factors affecting adoption of rapid composting in Mekong Delta, Vietnam and Central Luzon, Philippines. J Environ Sci Manag 15(2):59-73

Nguyen-V-Hieu, Nguyen-T-Nghi, Le-Q-Vinh, Le-M-Anh, Nguyen-V-Hung, Gummert M (2018) Developing densified products to reduce transportation costs and improve the quality of rice straw feedstocks for cattle feeding. J Viet Environ 10(1). https://oa.slub-dresden.de/ejournals/ jve/article/view/2919

Nguyen-V-Hung, Topno S, Balingbing C, Nguyen-V-C-Ngan, Roder M, Quilty J, Jamieson C, Thornley P, Gummert M (2016a) Generating a positive energy balance from using rice straw for anaerobic digestion. Energy Rep 2:117-122

Nguyen-V-Hung, Nguyen-D-Canh, Tran-V-Tuan, Hau-D-Hoa, Gummert M (2016b) Energy efficiency, greenhouse gas emissions, and cost of rice straw collection in the Mekong River Delta of Vietnam. Field Crops Res 198:16-22

Nguyen-V-Hung, Carlito B, Quilty J, Bojern S, Demont M, Gummert M (2017) Processing rice straw and rice husk as co-products. In: Sasaki T (ed) Achieving sustainable cultivation of rice, vol 2. Burleigh Dodds Science Publishing, Cambridge, pp 121-148

Peripolli V, Barcellos JO, Prates ÊR, Mcmanus C, Silva LP, Stella LA, Lopes RB (2016) Nutritional value of baled rice straw for ruminant feed. Rev Bras Zootec 45(7):392-399

Rozainee M, Ngo SP, Salema AA, Tan KG, Aiffin M et al (2008) Effect of fluidising velocity on the combustion of rice husk in a bench-scale fluidised bed combustor for the production of amorphous rice husk ash. Bioresour Technol 99:703-713

Sander BO, Samson M, Buresh RJ (2014) Methane and nitrous oxide emissions from flooded rice fields as affected by water and straw management between rice crops. Geoderma 235-236:355-362

Sarnklong C, Cone JW, Pellikaan W, Hendriks WH (2010) Utilization of rice straw and different treatments to improve its feed value for ruminants: a review. Asian-Aust J Anim Sci 23(5):680-692 
Satlewal A, Agrawal R, Bhagia S, Das P, Ragauskas AJ (2017) Rice straw as a feedstock for biofuels: availability, recalcitrance, and chemical properties. Biofuels Bioprod Biorefin 12(1):83-107

Topno SE (2015) Environmental performance and energy recoverable from stored rice straw bales in humid climate. Unpublished PhD thesis. University of the Philippines Los Baños

Yadvinder-Singh, Bijay-Singh, Ladha JK, Khind CS, Khera TS, Bueno CS (2004) Effects of residue decomposition on productivity and soil fertility in rice-wheat rotation. Soil Sci Soc Am J 68:854-864

Zafar S (2015) Rice straw as bioenergy resource. Bioenergy Consult. http://www.bioenergyconsult.com/tag/rice-residues/

Zhang Y, Ghaly AE, Li B (2012) Physical properties of rice residues as affected by variety and climatic and cultivation conditions in three continents. Am J Appl Sci 9(11):1757-1768

Open Access This chapter is licensed under the terms of the Creative Commons Attribution 4.0 International License (http://creativecommons.org/licenses/by/4.0/), which permits use, sharing, adaptation, distribution and reproduction in any medium or format, as long as you give appropriate credit to the original author(s) and the source, provide a link to the Creative Commons licence and indicate if changes were made.

The images or other third party material in this chapter are included in the chapter's Creative Commons licence, unless indicated otherwise in a credit line to the material. If material is not included in the chapter's Creative Commons licence and your intended use is not permitted by statutory regulation or exceeds the permitted use, you will need to obtain permission directly from the copyright holder.

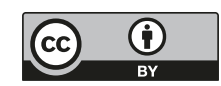

